\title{
Pollution and Probabilistic Human Health Risk Assessment of Potentially Toxic Elements in the Soil-water-plant System in the Bolkar Mining District, Niğde, South-central Turkey
}

Abdurrahman Lermi ( $\nabla$ alermi@ohu.edu.tr )

Niğde Ömer Halisdemir University: Nigde Omer Halisdemir Universitesi

Emmanuel Daanoba Sunkari

Niğde Ömer Halisdemir Üniversitesi: Nigde Omer Halisdemir Universitesi

\section{Research Article}

Keywords: anthropogenic activities, human health risk assessment, ore slags, pollution assessment, potentially toxic elements, arsenic contamination

Posted Date: May 4th, 2021

DOl: https://doi.org/10.21203/rs.3.rs-456493/v1

License: (c) (1) This work is licensed under a Creative Commons Attribution 4.0 International License. Read Full License

Version of Record: A version of this preprint was published at Environmental Science and Pollution Research on July 21st, 2021. See the published version at https://doi.org/10.1007/s11356-021-15398-w. 
Pollution and probabilistic human health risk assessment of potentially toxic elements

in the soil-water-plant system in the Bolkar mining district, Niğde, south-central Turkey

3

4 5

6

7

8

9

10
Abdurrahman Lermi ${ }^{1 *} \&$ Emmanuel Daanoba Sunkari ${ }^{1,2}$

${ }^{1}$ Department of Geological Engineering, Niğde Ömer Halisdemir University, 51240, Niğde, Main Campus, Turkey

${ }^{2}$ Department of Geological Engineering, University of Mines and Technology, Faculty of Mineral Resources Technology, P.O. Box 237, Tarkwa, Ghana

*Corresponding author: $\underline{\text { alermi @ ohu.edu.tr }}$

*ORCID: https://orcid.org/0000-0003-4117-689X

\section{Acknowledgement}

Mr. Gökhan KELEBEK is sincerely acknowledged for his role in sample collection during the Part A section of this study. The second author is grateful to the Scientific and Technological Research Council of Turkey (TÜBİTAK) for the continuous financial support as a doctoral research fellow.

\section{Ethics declarations}

Funding: The geochemical analysis in this study was financially supported by the Scientific Research Office (BAP) of Niğde Ömer Halisdemir University, Turkey with the project No: FEB 2007/07.

Ethics approval: The authors declare that the submitted manuscript is original. Authors also acknowledge that the current research has been conducted ethically and the final shape of the research has been agreed by both authors. Authors declare that this manuscript does not involve researching about humans or animals. 
Conflicts of interest/Competing interests: The authors declare no conflicts of interests/ competing interests.

Availability of data and material (data transparency): All data used in the study will be readily available to the public.

Code availability (software application or custom code): All software applications used in this study were the licensed software applications used by Niğde Ömer Halisdemir University, Turkey.

Consent to participate: The authors consent to participate in this research study.

Consent to publish: The authors consent to publish the current research in ESPR journal.

Authors' contributions: Abdurrahman Lermi: Conceptualization, Methodology, Investigation, Supervision, Writing-Original draft preparation, Validation, Writing- Reviewing and Editing. Emmanuel Daanoba Sunkari: Methodology, Software, Data curation, WritingOriginal draft preparation, Visualization, Writing-Reviewing and Editing.

\section{Highlights}

- Pollution assessment reveals moderate to extremely high pollution of PTEs in the soil.

- Water hazard index values indicate that $100 \%$ of the samples are of extreme toxicity.

- Bioconcentration factors show high levels of element transfer from the soil and water to the plants. 

water.

\section{Abstract}

Globally, potentially toxic elements (PTEs) are regarded as an important group of pollutants for the wider environment because of their intrinsic toxicity and probable accumulation in the soil-water-plant system. In this regard, this study assessed the pollution levels and probable human health risks of PTEs in the soil-water-plant system in the Bolkar mining district of the Niğde Province in south-central Turkey. Pollution assessment using contamination factor, enrichment factor, index of geoaccumulation, and soil pollution index reveals moderate to extremely high pollution of PTEs in the soil, exposing the soils to extreme toxicity levels. The areas that fall under the toxic to extremely toxic categories are in proximity to the ore slags and agricultural lands towards the central and southern domains of the study area. The water hazard index (WHI) values indicate that $100 \%$ of the samples collected in both winter and fall seasons are of extreme toxicity (WHI > 15). Arsenic is the dominant contaminant among the PTEs in the soil and water samples. The bioconcentration factor values of the PTEs in most of the fruit plants are $>1$, indicating very high levels of element transfer from the soil and water to the plants. The probabilistic human health risk assessment involved exposure to arsenic in groundwater (a major pathway to humans) since it is the only carcinogenic element in this study. The estimated daily intake of arsenic-contaminated water exceeds the safe limit of $5 \times$ $10^{-8} \mathrm{mg} / \mathrm{kg} /$ day. About $33.3 \%$ and $55.6 \%$ of the groundwater samples have higher hazard quotient and carcinogenic risk values of arsenic in the winter and fall seasons, respectively. This implies that the people are more exposed to the carcinogenic effects of drinking arseniccontaminated water. 
Keywords: anthropogenic activities; human health risk assessment; ore slags; pollution assessment; potentially toxic elements; arsenic contamination

\section{Introduction}

Potentially toxic elements (PTEs) are naturally dispersed through various environmental media with acceptable concentrations. However, due to the increasing rate of anthropogenic activities, the PTEs are being re-dispersed resulting in elevated concentrations (Elnazer and Salman 2020). Globally, it is well documented that the main anthropogenic sources of PTEs in the soilwater-plant system are mining activities, agricultural activities, sewage disposal, industrial and vehicular emissions (Lermi and Ertan 2019; Zango et al. 2019; Çiner et al. 2020; Kovacheva et al. 2020; Liu et al. 2020; Nganje et al. 2020). Among these, mining activities are the dominant routes of PTEs in the soil-water-plant system in metallogenic provinces. Ore slags left after mining can weather thereby releasing PTEs into the soil, which can in turn be leached into surface and groundwater resources and then become available for plant uptake. Excessive exposure to PTEs, especially Mn may lead to mental retardation and in extreme cases, Parkinson's disease ( $\mathrm{Li}$ et al. 2018; Rahman et al. 2021). Over exposure to $\mathrm{Cu}$ through industrial and mining activities can lead to liver damage and impairment of the central nervous system, and in some cases, it can lead to lung cancer (Giri and Singh 2017). In addition, most of the non-essential PTEs like $\mathrm{Pb}, \mathrm{As}, \mathrm{Hg}$, and $\mathrm{Cd}$ act as carcinogens and are the cause of many diseases, especially those involving the heart, nervous system, kidney, and bones (Järup 2003; Chiang et al. 2011; Zhan et al. 2014; Sunkari and Danladi 2016; Çiner et al. 2020).

A typical agricultural system involves the soil-water-plant nexus, which is essential for survival of the human race on earth. In this regard, the quality of the soil-water-plant system has become a global concern in the past decades. Although many published works were focused 
on soil, water, and plant quality, there is paucity of research on assessment of the soil-waterplant system pollution as well as the associated human health risks. A few studies considered the pollution of potentially toxic elements (PTEs) in the soil-water-plant system in some countries like Morocco (El Azhari et al. 2017), Egypt (Salman et al. 2017; Elnazer and Salman 2020), Bangladesh (Alam et al. 2020), Bulgaria (Kovacheva et al. 2020), and Nigeria (Nganje et al. 2020). The significance of these studies in national development is the use of models such as pollution and human health risk assessment indices to understand the sustainability of the soil-water-plant system in food production, to determine the sources and dispersion mechanisms of PTEs.

Human beings can be exposed to PTEs through consumption of water and food, inhalation of soil particles, and ingestion of soil (geophagia) (Elnazer and Salman 2020). Among all these routes, dietary intake of polluted food happens to be the principal route of PTEs in the human system (Ji et al. 2013). Pollution of foodstuff with PTEs is mostly due to soil pollution, which is a major setback to agricultural productivity in many parts of the world (Chauhan et al. 2018). Therefore, considering the intrinsic toxicity of PTEs and their potential accumulation in the soil-water-plant system, they are globally regarded as an important group of pollutants for the wider environment and thus, the need for human health risk assessment (Ngole-Jeme 2016). The potential human health risks from PTEs are generally assessed by carcinogenic and non-carcinogenic risk assessment methods such as lifetime exposure level $(\mathrm{ADD}$ life $)$ and hazard quotient (HQ) (Chen et al. 2018). By the use of these methods, the level of pollution loading can be ascertained, which will provide useful constraints to scale and determine potential health risks. In terms of the effect of the PTEs on plants, the bioconcentration factor (BCF) also referred to as biological adsorption coefficient (BAC) is widely used to determine the accumulation levels of PTEs from soil to plants (Kabata-Pendias 2011; Jiang et al. 2020; Luo et al. 2020; Nganje et al. 2020). However, contamination factor 
123 (CF), enrichment factor $(\mathrm{EF})$, index of geoaccumulation $\left(I_{g e o}\right)$, and soil pollution index (PI) 124 have been effectively used to estimate the extent of soil contamination by PTEs (e.g., Darwish and Pöllmann 2015; Kowalska et al. 2018; Dan-Badjo et al. 2019; Kabala et al. 2020; Lermi and Sunkari 2020; Nganje et al. 2020).

The Bolkar mining district is an ancient metallogenic province that has been under exploration since the 1880s. The ore deposits in this area are mostly chromite and Sb-W-HgAu deposits (Akçay et al. 1995), Mn deposits (Öztürk 1997; Lermi et al. 2016), MVT- and CRD-type Pb and Zn deposits (Hanilçi and Öztürk 2011; Hanilçi 2019), Fe-Zn skarn deposits Kusçu (2019), bauxite, Al and Fe-rich laterite deposits (Hanilçi 2013; Hanilçi 2019). Exploration and mining of these deposit types have left abundant ore slags (Fig. 1) in the area that are continuously being weathered and dispersed. Despite this threat to the soil-water-plant residing in the study area. 


\section{Materials and methods}

148

149

150

151

152

\subsection{Study area and sample collection}

The study area is located in the Niğde Province in the Gümüş village in the Central Anatolian Part of Turkey (Fig. 1). The climatic conditions prevailing in this area reflect that of continental climate where there is a period of dryness in the summer season and wetness in the winter season. The study area is bounded by high altitude mountains up to 3200 meters above sea level. The highest average precipitation is about $58 \mathrm{~mm}$ and mostly occurs in May, whereas the least average precipitation is about $5 \mathrm{~mm}$ and occurs in August. Temperatures are usually low to about $-5^{\circ} \mathrm{C}$ in January, whereas relatively high temperatures up to $22^{\circ} \mathrm{C}$ are usually recorded in July. The main rocks in the area are metamorphic rocks such as marble and schist and volcano-sedimentary rocks like pyroclastics, pillow lavas, andesite, basalt, limestone, dolomite, which are intruded by granitoids in some places (Fig. 1; Clark and Robertson 2002; Alpaslan et al. 2006; Lermi and Sunkari 2020). There are abundant ore slags in most parts of the study area due to the ancient mining activities (Fig. 1).

Details of the sample collection and analysis are presented in the Part A of this research (under-review). In all, a total of 40 composite samples were collected from the soil profile in the area and sent to the ACME Analytical Laboratories, Vancouver, Canada for analysis of PTEs using ICP-MS method. A total of 20 groundwater samples were collected in $500 \mathrm{ml}$ polyethylene bottles, acidified with nitric acid to a $\mathrm{pH}<2$ (Lermi and Ertan 2019) and then sent to the ACME Analytical Laboratories, Vancouver, Canada for analysis of PTEs using Ultra trace ICP-MS method. For the plants, leaves of fruit plants were collected in paper bags, washed, dried, ground in agate mortar, and filtered with a 100 mesh sieve (Dan-Badjo et al. 2019; Wang et al. 2019). About $1 \mathrm{~g}$ of the ground samples was acidified using $\mathrm{HNO}_{3}$ and 
analyzed in aqua regia by means of Ultra trace ICP-MS method at the ACME Analytical Laboratories, Vancouver, Canada.

\subsection{Pollution assessment}

\subsubsection{Contamination factor $\left(C_{f}\right)$}

Contamination factor $\left(\mathrm{C}_{\mathrm{f}}\right)$ is mostly used to assess the extent of soil pollution by PTEs, especially the metallic PTEs. In this study, the $\mathrm{C}_{\mathrm{f}}$ was calculated from the equation (1) after Hakanson (1980):

$$
\mathrm{CF}=\frac{C_{P T E}}{C_{B V}}
$$

where $\mathrm{CF}$ is the contamination factor, $C_{P T E}$ is the concentration of each PTE, and $C_{B V}$ is the background value of each PTE, which is the world average crustal value. The CF values calculated from the above equation were interpreted according to the four classes of contamination of Hakanson (1980); CF $<1$ (low contamination), $1 \leq \mathrm{CF} \leq 3$ (moderate contamination), $3 \leq \mathrm{CF} \leq 6$ (considerable contamination) and $\mathrm{CF}>6$ (very high contamination).

\subsubsection{Enrichment factor $(E F)$}

The EF was calculated by comparing the concentrations of the individual PTEs in the soils against average crustal values or unpolluted soil using data from Bowen (1979). In this study, the EF was assessed based on the background values of the PTEs in the average shale (Turekian and Wedepohl 1961). Aluminium was used as the normalization element because of its conservative nature even under extreme pedogenic processes (Ettler et al. 2006). The EF values of the studied soils were calculated from equation 2: 
$192 \quad \mathrm{EF}=\frac{\left(\mathrm{C}_{i} / \mathrm{C}_{A l}\right)_{s}}{\left(\mathrm{C}_{i} / \mathrm{C}_{A l}\right)_{b}}$

193

194

195

196

197

198

199

200

201

202

203

204

205

206

207

208

209

210

211

212

where $\left(C_{i} / C_{A l}\right) s$ is the $\mathrm{PTE} / \mathrm{Al}$ ratio in the samples and $\left(C_{i} / C_{A l}\right) b$ is the $\mathrm{PTE} / \mathrm{Al}$ ratio in the background sample (average shale). For assessing the enrichment levels of the individual PTEs, five classes have been suggested by Andrews and Sutherland (2004); EF < 2 (minimal pollution), EF 2 - 5 (moderate pollution), EF 5 - 20 (significant pollution), EF 20 - 40 (high pollution) and $\mathrm{EF}>40$ (extreme pollution).

\subsubsection{Index of geoaccumulation ( $\left.I_{\text {geo }}\right)$}

The level of anthropogenic influence of each PTE on the soil was assessed using the index of geoaccumulation ( $\left.I_{g e o}\right)$ by Müller (1969), equation 3:

$$
I_{\text {geo }}=\log _{2}\left[\frac{C_{n}}{1.5 B_{n}}\right]
$$

where $C_{n}$ is the PTE $(n)$ concentration and $B_{n}$ represents the background concentration of that PTE $(n)$ in the average shale. The factor 1.5 permits assessment of the fluctuations of the natural content of the PTE in the environment (Wei et al. 2009). The interpretation of the calculated $I_{\text {geo }}$ values was based on the classification scheme of (Müller 1981); $I_{g e o}<0$ (no pollution), $0 \leq$ $I_{g e o} \leq 1$ (no to moderate pollution), $1 \leq I_{\text {geo }} \leq 2$ (moderate pollution), $2 \leq I_{\text {geo }} \leq 3$ (moderate to heavy pollution), $3 \leq I_{g e o} \leq 4$ (heavy pollution), $4 \leq I_{\text {geo }} \leq 5$ (heavy to extreme pollution), and $I_{g e o}>5$ (extreme pollution). 
214 The contamination of PTEs in soil, especially in mining areas is usually a combination of 215 several contaminants rather than a single element (Lee et al. 2006). In this regard, the concept 216 of soil pollution index (PI) has become an effective way of assessing the combined influence of multi-elements on soils (Smouni et al. 2010; Dan-Badjo et al. 2013, 2019; Nganje et al. 2020). The PI is a criterion for assessing the overall toxicity of PTEs and its computation varies among different workers but the basic concept is the same. In this study, the PI of the soil was computed as the average ratio of metal concentration in the soil samples to background values of the metals (Bowen 1979) from equation 4:

$$
\mathrm{PI}=\left\{\left(\frac{\mathrm{As}}{5}\right)+\left(\frac{\mathrm{Cd}}{0.06}\right)+\left(\frac{\mathrm{Co}}{29}\right)+\left(\frac{\mathrm{Cu}}{30}\right)+\left(\frac{\mathrm{Hg}}{0.03}\right)+\left(\frac{\mathrm{Mo}}{2}\right)+\left(\frac{\mathrm{Ni}}{40}\right)+\left(\frac{\mathrm{Pb}}{20}\right)+\left(\frac{\mathrm{Zn}}{50}\right)\right\} / 9 \quad 4
$$

where $\mathrm{As}, \mathrm{Cd}, \mathrm{Co}, \mathrm{Cu}, \mathrm{Hg}, \mathrm{Mo}, \mathrm{Ni}, \mathrm{Pb}$, and $\mathrm{Zn}$ are the concentrations of these PTEs in the soil samples whereas the denominators are their background values in unpolluted soil (Bowen 1979; Lindsay 1979). PI > 1 indicates that the soil is polluted by several PTEs owing to anthropogenic input. Generally, PI values $<5$ indicate low toxicity, PI values between 5 and 10 indicate slight toxicity, PI values between 10 and 20 indicate moderate toxicity and PI values $>20$ indicate extreme toxicity (Chon et al. 1996).

\subsubsection{Water hazard index (WHI)}

The water hazard index (WHI) was used in assessing the overall impact of the PTEs on water resources in the study area. It was computed as a ratio of the concentration of the individual PTEs to their maximum guideline values for drinking water in Turkey (TSE-266 2005). 
$235 \quad$ WHI $=\left\{\left(\frac{\mathrm{As}}{0.01}\right)+\left(\frac{\mathrm{Cu}}{3}\right)+\left(\frac{\mathrm{Sb}}{0.01}\right)+\left(\frac{\mathrm{Pb}}{0.05}\right)+\left(\frac{\mathrm{Zn}}{5}\right)\right\} / 5$

236

237

238

239

240

241

242

243

$245 \quad \mathrm{BCF}=\frac{\mathrm{CMIP}}{\mathrm{CMIS}}$

where $\mathrm{As}, \mathrm{Cu}, \mathrm{Sb}, \mathrm{Pb}$, and $\mathrm{Zn}$ are the concentrations of these PTEs in the water samples and the denominators are their standard guideline values in drinking water obtained from the Turkish Standards Institute (TSE-266 2005). The following categories of interpretation of the computed WHI values (Nganje et al. 2020) were used; WHI $<5$ (low to minimal toxicity), $5 \leq$ $\mathrm{WHI} \leq 10$ (slightly toxic), $10 \leq \mathrm{WHI} \leq 15$ (moderately toxic) and WHI $>15$ (extremely toxic).

\subsubsection{Bioconcentration factor $(B C F)$}

The bioconcentration factor $(\mathrm{BCF})$ is used to evaluate the accumulation levels of plants for the PTEs (Wang et al. 2019). It was calculated using equation 6:

where CMIP is the concentration of the metal in the plants and CMIS is the concentration of the metal in the soil.

\subsection{Probabilistic human health risk assessment}

\subsubsection{Exposure assessment}

The exposure assessment reveals the routes and pathways through which humans are exposed to contaminants and estimates the amount, frequency and duration of exposure. In this study, the exposure assessment was limited to the water medium since the people largely depend on groundwater for drinking and irrigation purposes. The PTEs considered in this assessment include $\mathrm{As}, \mathrm{Cd}, \mathrm{Ni}, \mathrm{Pb}$, and $\mathrm{Zn}$ based on their elevated concentrations in groundwater. The 
average daily dose (ADD) of the contaminant in the water was computed using the model of

257 the United States Environmental Protection Agency (USEPA 1997, 2004).

$$
\mathrm{ADD}=\frac{\mathrm{C} \times \mathrm{IR} \times \mathrm{ED} \times \mathrm{EF}}{\mathrm{BW} \times \mathrm{AT}}
$$

259

260

261

$271 \quad \mathrm{HQ}=\frac{\mathrm{ADD}}{\mathrm{R} f \mathrm{D}}$ quotient (HQ):

where $\mathrm{C}$ is the concentration of the PTE in the water $(\mathrm{mg} / \mathrm{L})$, IR represents the ingestion rate (2 L/day) taken from (USEPA 2004), ED is the exposure duration (years) to the PTEs and according to the archives of the USEPA (USEPA 1997), 30 years is used, EF denotes the exposure frequency (days/year) taken as 365 days/year (USEPA 2004), BW is the average body weight (kg) (61.75) from Çiner et al. (2020), AT is the average time of exposure (d) and in this study, for the non-carcinogenic risk, $\mathrm{AT}=\mathrm{ED} \times 365$ and for carcinogenic risk, $\mathrm{AT}=77.434 \times$ 365 since 77.434 is the average life expectancy of people living in Turkey (Karacan et al. 2020).

\subsubsection{Non-carcinogenic risk assessment}

Non-carcinogenic risk refers to toxic risks that are not up to the extent of causing cancers but cause harm to consumers due to exposure to PTEs. It is mostly computed in terms of hazard

where RfD is the reference dose, which is taken from the United States Integrated Risk Information System for the individual PTEs (USEPA 2011). The RfD for As, Ni, Pb, Zn, and Sb are $3 \times 10^{-4}, 2 \times 10^{-2}, 3.5 \times 10^{-3}, 3 \times 10^{-1}$, and $4 \times 10^{-4} \mathrm{mg} / \mathrm{kg} /$ day, respectively. In assessing the non-carcinogenic risk, if the computed HQ exceeds 1 , then it is interpreted that there is a potential health risk with respect to the particular element. 
279

280

Among the PTEs detected in the water samples in the study area, only arsenic is a carcinogen. Therefore, the carcinogenic risk (CR) associated with exposure to the intake of arsenic through the water samples collected from the study area was computed using the model of the USEPA (1989):

$$
\mathrm{CR}=\mathrm{ADD}_{\text {life }} \times \mathrm{SF}
$$

where $\mathrm{ADD}_{\text {life }}$ is the lifetime exposure level and is calculated by estimating the exposure suffered during the exposure duration over the life expectancy of the individual. SF $(\mathrm{mg} / \mathrm{kg} /$ day) is the slope factor, which indicates the probability of having cancer due to exposure to arsenic. The SF for arsenic according to USEPA (2011) is $1.5 \mathrm{mg} / \mathrm{kg} / \mathrm{day}$. Computed CR values above $1 \times 10^{-4}$ suggest that there is a carcinogenic risk with respect to exposure to arsenic for both children and adults (Zhang et al. 2019).

\section{Results and discussion}

\subsection{Levels of pollution of PTEs in soil}

Statistical summaries of concentrations of PTEs in the soil and the pollution assessment are given in Tables 1 and 2, respectively. The PTEs vary in the order $\mathrm{Au}<\mathrm{Th}<\mathrm{U}<\mathrm{Co}<\mathrm{Bi}<\mathrm{Mo}$ $<\mathrm{Ag}<\mathrm{V}<\mathrm{Sr}<\mathrm{Sb}<\mathrm{Ni}<\mathrm{Cu}<\mathrm{Mn}<\mathrm{Zn}<\mathrm{Hg}<\mathrm{Cd}<\mathrm{Pb}<$ As (Table 1), indicating that As is the most dominant potentially toxic element in the soil samples. In terms of contamination factors $(\mathrm{CF})$, only $\mathrm{Mn}$ and $\mathrm{Co}$ are in the class of low $(\mathrm{CF}<1)$ to moderate $(1 \leq \mathrm{CF} \leq 3)$ contamination, whereas $\mathrm{As}, \mathrm{Cd}, \mathrm{Cu}, \mathrm{Mo}, \mathrm{Pb}, \mathrm{Zn}$, and $\mathrm{Sb}$ fall in the class of low $(\mathrm{CF}<1)$ to very high $(\mathrm{CF}>6)$ contamination. However, $\mathrm{Ni}$ is in the class of moderate to very high contamination. The computed enrichment factor (EF) values also show that $\mathrm{Mn}$ is in the class 
of moderate $(2 \leq \mathrm{EF} \leq 5)$ to significant $(5 \leq \mathrm{EF} \leq 20)$ pollution, Co in the class of moderate (2 $\leq \mathrm{EF} \leq 5)$ to high $(20 \leq \mathrm{EF} \leq 40)$ pollution, $\mathrm{As}, \mathrm{Cd}, \mathrm{Cu}, \mathrm{Mo}, \mathrm{Pb}, \mathrm{Zn}$, and $\mathrm{Sb}$ in the class of minimal $(\mathrm{EF}<2)$ to extreme pollution $(\mathrm{EF}>40)$. But the EF values of Ni show significant to extreme pollution. Accordingly, EF values of soil that ranges from 0.5 to 1.5 indicate that PTEs in the soil are mostly coming from crustal or geogenic sources whereas EF values higher than 1.5 reflect large input from anthropogenic sources (Zhang and Liu 2002; Lermi and Sunkari 2020). In the current study, the mean EF values for the investigated PTEs are all above 1.5, indicating that contribution from slag piles in the area and agricultural activities, which are the main anthropogenic sources of PTEs is intense. For the index of geoaccumulation $\left(I_{g e o}\right)$ values, $\mathrm{Mn}$ and Co fall in the class of no to moderate pollution $\left(0 \leq I_{g e o} \leq 1\right)$, Mo is in the class of no $\left(I_{\text {geo }}<0\right)$ to heavy $\left(3 \leq I_{\text {geo }} \leq 4\right)$ pollution, whereas $\mathrm{As}, \mathrm{Cd}, \mathrm{Cu}, \mathrm{Pb}, \mathrm{Zn}$, and $\mathrm{Sb}$ are in the class of no $\left(I_{g e o}<0\right)$ to extreme $\left(I_{g e o}>5\right)$ pollution. Nevertheless, Ni is distinctly within the moderate to heavy pollution class. This suggests that the results of the CF, EF and $I_{\text {geo }}$ assessments corroborate with each other. Thus, it is clear that the soil samples have varied levels of pollution with regard to $\mathrm{Mn}, \mathrm{As}, \mathrm{Cd}, \mathrm{Co}, \mathrm{Cu}, \mathrm{Mo}, \mathrm{Pb}, \mathrm{Zn}$, and $\mathrm{Sb}$. The values computed from the soil pollution index (PI) assessment revealed that the PI values ranged from 2.51 (low toxicity potential) to 407 (extreme toxicity potential) (Table 1). All the samples have PI values $>1$ (Table 1), suggesting that relatively high contents of PTEs are in the soils of the historical Bolkar mining area, exposing the soils to extreme toxicity levels. The lowest PI values are around the non-mine and non-agricultural areas without slag piles indicating low accumulation of the PTEs in these areas (Fig. 2). The areas that fall under the toxic to extremely toxic classes are in proximity to the slag piles and agricultural lands towards the central and southern domains of the study area (Fig. 2). Interestingly, the PI values in this study are higher than PI values in other studies elsewhere in the world (Smouni et al. 2010; Dan-Badjo et al. 2019; Nganje et al. 2020). For instance, in the mining areas of eastern 
Morocco, Smouni et al. (2010) reported PI values in the range of $0.08-47.7$, lower than those reported in this study. This confirms the fact that the proximity of the ore slags to the sampling sites is a contributory factor to the pollution of the PTEs in the soil.

\subsection{Levels of pollution of PTEs in water}

Statistical summary of the concentrations of PTEs in the water samples is given in Table 3. Among the PTEs, arsenic (As) has the highest concentration ranging from $0.80-287 \mu \mathrm{g} / \mathrm{L}$ with a median of $2.90 \mu \mathrm{g} / \mathrm{L}$ in the winter season, whereas the concentration varied from 1.20 to $373 \mu \mathrm{g} / \mathrm{L}$ with a median of $9 \mu \mathrm{g} / \mathrm{L}$ in the fall season (Table 3). The water hazard index (WHI) values indicate that $100 \%$ of the samples collected in both seasons are of extreme toxicity (WHI $>15$ ) (Fig. 3). The combined effect of multi-PTEs is therefore very evident in the studied water samples. During the winter season, the WHI values varied in the range of $35.9-6334$ (Fig. 3), whereas in the fall season the WHI values significantly increased from 42.6 to 8805 (Fig. 3). Certainly, the water in the vicinity of the ore slags is highly polluted and thus, detrimental to human health.

\subsection{Bioaccumulation effect of PTEs in plants}

Table 4 contains statistical summary of the concentrations of plant samples in this study. The average concentrations of the PTEs in the fruit plants vary in the order of $\mathrm{Zn}<\mathrm{As}<\mathrm{Pb}<\mathrm{Fe}$, implying that $\mathrm{Fe}$ is the most enriched element in the plants. Plants can only absorb some of the elements in the soil through cation exchange. Some authors state that the most suitable amount of elements for biological nutrition is equivalent to the amounts in groundwater (Nguyen et al., 2005). Therefore, to clearly understand the bioaccumulation capacities of the plants, the bioconcentration factors (BCF) were computed. The BCF is a factor that indicates the degree 
of the plant to absorb PTEs from the surrounding water resources (Nguyen et al. 2005). The results indicate that the fruit plants in the region copiously absorb $\mathrm{Fe}, \mathrm{Pb}, \mathrm{Zn}$, and $\mathrm{As}$ and act like bio-accumulators (Table 4). Moreover, the BCF for most of the fruit plants are > 1 (Table 4), indicating very high levels of element transfer from the soil and water to the plants. This is attributed to the high solubility of most secondary minerals in the area under alkaline conditions (Kabata-Pendias and Pendias 2000). Bioaccumulation of PTEs by plants is potentially detrimental to the organisms that feed on the leaves and fruits of these plants and may cause undesirable disorders in the long term. Essentially, the high BCF values suggest that human health and plant growth in the region are under jeopardy. Therefore, the stakeholders in the area should take necessary measures to curtail the menace.

\subsection{Constraints from probabilistic human health risk assessment}

In terms of the computed estimated daily intake (EDI) values for the various PTEs, arsenic (As) appears to be the element dominant in groundwater in both seasons and the people are more exposed to the intake of arsenic-contaminated groundwater than the other PTEs (Tables 5 and 6). The EDI values of As range from 0.00003 to $0.00929 \mathrm{mg} / \mathrm{kg} /$ day in the winter season indicating that the inhabitants of the study area are all exposed to the health implications emanating from the intake of As-contaminated water (Zhang et al. 2019). The results obtained in this study can be compared with that of Zhang et al. (2019) and Barzegar et al. (2019) who reported higher EDI values of As in groundwater in China and Iran, respectively.

The UESEPA (1989) indicated that when the hazard quotient (HQ) values of 
associated with the consumption of water contaminated with PTEs. This study reports higher HQ values for As in the winter season (0.08637 - 30.97436; Table 5) and fall season (0.12955 - 40.21592; Table 6). About 33.3\% of the water samples have higher HQ values of As in the winter season, whereas $55.6 \%$ of the water samples have higher HQ values of As in the fall season. Comparing this with the EDI values in both seasons, it can be concluded that the residents of the study area drink more water in the fall season due to the high temperature conditions and are thus, more exposed to the non-carcinogenic effects of drinking groundwater enriched in arsenic. Apart from As, in the winter season, one sample representing $11.1 \%$ of the total samples has $\mathrm{HQ}$ value with respect to $\mathrm{Pb}>1$ and 2 samples representing $22.2 \%$ of the total samples also have HQ values with respect to $\mathrm{Sb}>1$ (Table 5). However, in the fall season, only 2 samples have HQ values with respect to Sb exceeding the safe limit of 1 (Table 6).

The carcinogenic risk $(\mathrm{CR})$ is expressed in terms of the probability that one is likely to have cancer owing to the intake of arsenic-contaminated water during a lifetime exposure of approximately 77 years, since that is the life expectancy age for people living in Turkey (Karacan et al. 2020). The CR of being exposed to As by the drinking water is in the range of 0.00002 to 0.00540 in the winter season (Table 5). This suggests that some of the samples have high $\mathrm{CR}$ values in view of the safe limit of $1 \times 10^{-4}$. Just like the HQ values for As, approximately $33.3 \%$ of the samples have CR values above the safe limit (Table 5). Moreover, the $C R$ values are relatively higher in the fall season varying in the range of 0.00002 to 0.00701 (Table 6). It is also worth mentioning that the CR values exceed the safe limit of $1 \times 10^{-4}$ in almost $55.6 \%$ of the samples in the fall season, similar to the trend shown by the HQ values with respect to As in the fall season (Table 6). Definitely, the As concentrations in the water samples are extremely high exposing the people to the risk of carcinogenesis or keratinization of the skin (Health and Environment 2016). This calls for a great deal of attention by the government and key stakeholders in the historical Bolkar mining area within the Nigde 
Province. The results of this study have provided evidence for a nexus among soils, plants and water in the area.

\section{Conclusion}

This study was conducted to assess the pollution levels and probable human health risks associated with the dispersion of potentially toxic elements (PTEs) into the soil-water-plant system of the Bolkar mining district in south-central Turkey. The soil samples have soil pollution index values $>1$, suggesting that relatively high contents of PTEs are in the soils of the historical Bolkar mining area, exposing the soils to extreme toxicity levels. Other pollution assessment indexes such as contamination factor, enrichment factor, and index of geoaccumulation reveal that the soils are moderately to extremely polluted with respect to the PTEs. For the water samples, $100 \%$ of the samples collected in both winter and fall seasons show extreme toxicity (WHI > 15) for the PTEs. The fruit plants also show high levels of bioaccumulation in terms of their $\mathrm{Fe}, \mathrm{Pb}, \mathrm{Zn}$, and As concentrations. The human health risk assessment indicates that the water poses significant cancer risks due to the high arsenic content. The carcinogenic risk is associated with $55.6 \%$ of groundwater in the area, raising an alarm for the vulnerable population. In all, this study has provided significant data for the monitoring and management of mine waste in the historical Bolkar mining district. 


\section{References}

423

424

Akçay M (1995) Fluid inclusions and chemistry of tourmalines from the Gümüşler Sb-Hg $\pm W$ deposits of the Niğde Massif (Central Turkey). Chemie der Erde 55:225-236.

Alpaslan M, Boztuğ D, Frei R, Temel A, Kurt MA (2006) Geochemical and Pb-Sr-Nd isotopic composition of the ultrapotassic volcanic rocks from the extension-related Çamard1Ulukışla basin, Niğde Province, Central Anatolia, Turkey. Journal of Asian Earth Sciences 27(5):613-627.

Andrews S, Sutherland RA (2004) Cu, Pb and Zn contamination in Nuuanu watershed, Oahu, Hawaii. Science of the Total Environment 324(1-3):173-182.

Barzegar R, Moghaddam AA, Adamowski J, Nazemi AH (2019) Assessing the potential origins and human health risks of trace elements in groundwater: a case study in the Khoy plain, Iran. Environ Geochem Health 41(2):981-1002.

Bowen HJM (1979) Environmental Chemistry of Elements. Academic Press, London, 333 p.

Chauhan PS, Mishra SK, Misra S, Dixit VK, Pandey S, Khare P, Khan MH, Dwivedi S, Lehri A (2018) Evaluation of fertility indicators associated with arsenic contaminated paddy fields soil. Int J Environ Sci Technol 15:2447-2458.

Chen T, Lei C, Yan B, Li LL, Xu DM, Ying GG (2018) Spatial distribution and environmental implications of heavy metals in typical lead $(\mathrm{Pb})$-zinc $(\mathrm{Zn})$ mine tailings impoundments in Guangdong Province, South China. Environ. Sci. Pollut. Res 25:36702-36711.

Chiang CT, Chang CK, Hwang YH, Yuan TH, Su CC, Tsai KY, Lian L (2011) A critical exploration of blood and environmental Chromium concentration among oral cancer 

476.

Chon HT, Cho CH, Kim KW, Moon HS (1996) The occurrence and dispersion of potentially toxic elements in areas covered with black shales and slates in Korea. Appl. Geochem 11:69-76.

Çiner F, Sunkari ED, Şenbaş BA (2020) Geochemical and Multivariate Statistical Evaluation of Trace Elements in Groundwater of Niğde Municipality, South-Central Turkey: Implications for Arsenic Contamination and Human Health Risks Assessment. Archives of Environmental Contamination and Toxicology 1-19. https://doi.org/10.1007/s00244-020-00759-2.

Clark M, Robertson A (2002) The role of the Early Tertiary Ulukisla Basin, southern Turkey, in suturing of the Mesozoic Tethys Ocean. Journal of the Geological Society 159(6):673-690.

Dan-Badjo AT, Guero Y, Dan Lamso N, Tidjani AD, Ambouta KJM, Feidt C, Sterckeman T, Echevarria G (2013) Evaluation de la contamination des sols par les éléments traces métalliques dans les zones urbaines et périurbaines de la ville de Niamey (Niger). Revue des BioRessources 2(2):82-95.

Dan-Badjo AT, Ibrahim OZ, Guéro Y, Morel JL, Feidt C, Echevarria G (2019) Impacts of artisanal gold mining on soil, water and plant contamination by trace elements at Komabangou, Western Niger. Journal of Geochemical Exploration 205:106328.

Darwish MAG, Pöllmann H (2015) Trace elements assessment in agricultural and desert soils of Aswan area, south Egypt: Geochemical characteristics and environmental impacts. Journal of African Earth Sciences 112:358-373. 
El Azhari A, Rhoujjati A, El Hachimi ML, Ambrosi JP (2017) Pollution and ecological risk assessment of heavy metals in the soil-plant system and the sediment-water column around a former $\mathrm{Pb} / \mathrm{Zn}$-mining area in NE Morocco. Ecotoxicol Environ Saf 144:464474.

Elnazer AA, Salman SA (2020) Critical load model and pollution indices application for watersoil-plant system assessment around El-Hammam canal, East El-Alamein, Egypt. International Journal of Environmental Science and Technology 3:1-2.

Ettler V, Mihaljevič M, Šebek O, Molek M, Grygar T, Zeman J (2006) Geochemical and Pb isotopic evidence for sources and dispersal of metal contamination in stream sediments from the mining and smelting district of Prríbram, Czech Republic. Environmental pollution 142(3):409-417.

Giri S, Singh AK (2017). Human health risk assessment due to dietary intake of heavy metals through rice in the mining areas of Singhbhum Copper Belt, India. Environmental Science and Pollution Research 24(17):14945-14956.

Hakanson L (1980) An ecological risk index for aquatic pollution control. A sedimentological approach. Water research 14(8):975-1001.

Hanilçi N (2013) Geological and geochemical evolution of the Bolkardaği bauxite deposits, Karaman, Turkey: transformation from shale to bauxite. Journal of Geochemical Exploration 133:118-137.

Hanilçi N (2019) Bauxite deposits of Turkey. In: Pirajno F, Dönmez C Şahin MB (ed) Mineral Resources of Turkey. Modern Approaches in Solid Earth Sciences. Springer Nature Switzerland 16(15):681-730. 
Hanilçi N, Öztürk H (2011) Geochemical/isotopic evolution of Pb-Zn deposits in the Central and Eastern Taurides, Turkey. International Geology Review 53(13):1478-1507.

Health and Environment (2016) Chemical environment: Arsenic. https://www.healthandenvironment.org/environmental-health/environmental $\underline{\text { risks/chemical environment-overview/arsenic. Accessed Aug } 2016 .}$

Järup L (2003) Hazards of heavy metal contamination. Br. Med. Bull 68:167-182.

Ji K, Kim J, Lee M, Park S, Kwon HJ, Cheong HK, Jang JY, Kim DS, Yu S, Kim YW (2013) Assessment of exposure to heavy metals and health risks among residents near abandoned metal mines in Goseong, Korea. Environ Pollut 178C:322-328.

Jiang F, Ren B, Hursthouse A, Deng R (2020) Evaluating health risk indicators for PTE exposure in the food chain: evidence from a thallium mine area. Environmental Science and Pollution Research 1-9.

Kabala C, Galka B, Jezierski P (2020) Assessment and monitoring of soil and plant contamination with trace elements around Europe's largest copper ore tailings impoundment. Science of the Total Environment 738: 139918. https://doi.org/10.1016/j.scitotenv.2020.139918.

Kabata-Pendias A (2011) Trace elements in soils and plants/fourth editions. CRC Taylor and Francis Group, Boca Raton, p.505.

Kabata-Pendias A, Pendias H (2000) Trace Elements in Soil and Plants. CRC Press, Boca Raton, Florida.

Karacan I, Sennaroglu B, Vayvay O (2020) Analysis of life expectancy across countries using a decision tree. Eastern Mediterranean Health J 26(2):143-151. 
Kovacheva A, Vladov I, Gabrashanska M, Rabadjieva D, Tepavitcharova S, Nanev V, Dassenakis M, Karavoltsos S (2020) Dynamics of trace metals in the system watersoil-plant-wild rats-tapeworms (Hymenolepis diminuta) in Maglizh area, Bulgaria. J Trace Elem Med Biol 58:126440. https://doi.org/10.1016/j.jtemb.2019.126440.

Kowalska JB, Mazurek R, Gąsiorek M, Zaleski T (2018) Pollution indices as useful tools for the comprehensive evaluation of the degree of soil contamination-A review. Environmental Geochemistry and Health 40(6):2395-2420.

Kuşcu İ (2019) Skarns and Skarn Deposits of Turkey. In Mineral Resources of Turkey. Cham, Switzerland: Springer, pp. 283- 336.

Lee CS, Li X, Shi W, Cheung SC, Thornton I (2006) Metal contamination in urban, suburban, and country park soils of Hong Kong: a study based on GIS and multivariate statistics. Sci. Total Environ 356 (1):45-61.

Lermi A, Ertan G (2019) Hydrochemical and isotopic studies to understand quality problems in groundwater of the Niğde Province, Central Turkey. Environmental Earth Sciences 78(12):365.

Lermi A, Sönmez M, Aydin F (2016) Mineralogy and Geochemistry of the Kiziltepe (ÇamardiNiğde) Mn Prospect in Central Anatolia, Turkey. International Multidisciplinary Scientific GeoConference: SGEM: Surveying Geology \& Mining Ecology Management 1:421-428.

Lermi A, Sunkari ED (2020) Geochemistry, risk assessment, and Pb isotopic evidence for sources of heavy metals in stream sediments around the Ulukışla Basin, Niğde, southern Turkey. Turkish Journal of Earth Sciences 29(7):1167-1188. https://doi.org/10.3906/yer-2001-9. 
533 Li L, Yang X (2018) The essential element manganese, oxidative stress, and metabolic diseases: links and interactions. Oxidative medicine and cellular longevity.

Lindsay WL (1979) Chemical Equilibria in Soils. John Wiley and Sons, New York.

Liu G, Shi Y, Guo G, Zhao L, Niu J, Zhang C (2020) Soil pollution characteristics and systemic environmental risk assessment of a large-scale arsenic slag contaminated site. Journal of Cleaner Production 251:119721.

Luo X, Ren B, Hursthouse AS, Jiang F, Deng RJ (2020) Potentially toxic elements (PTEs) in crops, soil, and water near Xiangtan manganese mine, China: potential risk to health in the foodchain. Environmental Geochemistry and Health 1-12.

Müller G (1969) Index of geoaccumulation in sediments of the Rhine River. Geojournal, 2: $108-118$.

Nganje TN, Edet A, Cuthbert S, Adamu CI, Hursthouse AS (2020) The concentration, distribution and health risk from potentially toxic elements in the soil-plant-water system developed on black shales in SE Nigeria. Journal of African Earth Sciences 103806. https://doi.org/10.1016/j.jafrearsci.2020.103806.

Ngole-Jeme VM (2016) Heavy metal in soils along unpaved roads in South West Cameroon:

Nguyen HL, Leermakers M, Elskens M, Ridder FD, Doan TH, Baeyens W (2005) Correlations, partitioning and bioaccumulation of heavy metals between different compartments of

Öztürk H (1997) Manganese deposits in Turkey: distribution, types and tectonic setting. Ore Geology Reviews 12(3):187-203. 
Rahman MA, Hashem MA, Rana MS, Islam MR (2021) Manganese in potable water of nine districts, Bangladesh: Human health risk. Environ Sci Pollut Res. https://doi.org/10.1007/s11356-021-14016-z.

Salman SA, Elnazer AA, El Nazer HA (2017) Integrated mass balance of some heavy metals fluxes in Yaakob village, south Sohag, Egypt. Int J Environ Sci Technol 14:1011-1018.

Smouni A, Ater M, Auguy F, Laplaze L, El Mzibri M, Berhada F, Doumas P (2010) Évaluation de la contamination par les éléments-traces métalliques dans une zone minière du Maroc oriental. Cahiers Agricultures 19(4):273-279.

Sunkari ED, Danladi IB (2016) Assessment of trace elements in selected bottled drinking water in Ghana: a case study of Accra metropolis. Int. J. Water Resour. Environ. Eng 8(10):137-142. https://doi.org/10.5897/IJWREE2016.0685.

TSE-266 (2005) Içme Suları Standardı. Türk Standartları Enstitüsü, Baskı TSE, TS, Ankara 266:1-25.

Turekian KK, Wedepohl KH (1961) Distribution of the elements in some major units of the earth's crust. Geological Society of America Bulletin 72(2):175-192.

US EPA (1997) Exposure Factor Handbook (EPA/600/p-95/002Fa) (Update to Exposure Factors Handbook EPA/600/8-89/043). Environmental Protection Agency Region I, Washington DC.

USEPA (1989) Risk Assessment Guidance for Superfund. Volume I: Human Health Evaluation Manual (Part A). US Environmental Protection Agency EPA/540/1-89/002. 
USEPA (2004) US EPA Office of Water. Office of Science and Technology (EPA-822-R-00001). Environmental Protection Agency Region I, Washington DC 20460. www.epe.gov/safewater.

USEPA IRIS (2011) US Environmental Protection Agency)'s Integrated Risk Information System. Environmental Protection Agency Region I, Washington DC, pp. 20460. http://www.epa.gov/iris.

Wang Z, Liu X, Qin H (2019) Bioconcentration and translocation of heavy metals in the soilplants system in Machangqing copper mine, Yunnan Province, China. Journal of Geochemical Exploration 200:159-166. https://doi.org/10.1016/j.gexplo.2019.02.005.

Wei B, Jiang F, Li X, Mu S (2009) Spatial distribution and contamination assessment of heavy metals in urban road dusts from Urumqi, NW China. Microchemical Journal 93(2):147152.

Zango MS, Sunkari ED, Abu M, Lermi A (2019) Hydrogeochemical controls and human health risk assessment of groundwater fluoride and boron in the semi-arid North East region of Ghana. Journal of Geochemical Exploration 207:106363.

Zhan HY, Jiang YF, Yuan J, Hu XF, Nartey OB, Wang BL (2014). Trace metal pollution in soil and wild plants from lead-zinc smelting areas in Huixian County, Northwest China. Journal of Geochemical Exploration 147: 182-188. http://dx.doi.org/10.1016/j.gexplo.2014.10.007.

Zhang J, Liu CL (2002) Riverine composition and estuarine geochemistry of particulate metals in China-weathering features, anthropogenic impact and chemical fluxes. Estuarine, Coastal and Shelf Science 54(6):1051-1070. 
601

602

603

604

605

606

607

608

609

610

611

612

613

614

615

616

617

Zhang Y, Xu B, Guo Z, Han J, Li H, Jin L, Chen F, Xiong Y (2019) Human health risk assessment of groundwater arsenic contamination in Jinghui irrigation district, China. Journal of environmental management 237:163-169.

\section{List of Tables}

Table 1. Statistical summary of concentrations of PTEs in soil samples in the study area (all PTEs are measured in ppm; $\mathrm{Al}, \mathrm{Fe}, \mathrm{Mg}$, and Ti are measured in wt.\%; PI = Soil Pollution Index; NSAS = Number of Samples Above Standard; Standard values taken from Bowen 1979)

Table 2. Soil pollution assessment using contamination factor (CF), enrichment factor (EF), and index of geoaccumulation $\left(I_{g e o}\right)$

Table 3. Statistical summary of concentrations of PTEs in water samples in the study area (all ions are measured in $\mathrm{mg} / \mathrm{L}$, whereas PTEs are measured in $\mu \mathrm{g} / \mathrm{L}$ )

Table 4. Statistical summary of the concentrations of PTEs in fruit plant samples in the study area ( $\mathrm{Au}$ and $\mathrm{Hg}$ are measured in $\mathrm{ppb}$, whereas the other elements are measured in $\mathrm{ppm}$ )

Table 5. Health risk assessment of groundwater in the winter season

Table 6. Health risk assessment of groundwater in the fall season

\section{Figure Captions}

618 Figure 1. Location and geology map of the study area (after Lermi and Sunkari 2020) 
619 Figure 2. Spatial distribution of soil pollution index values

620 Figure 3. Water hazard index (WHI) for (a) winter season and (b) fall season

621

622

623

624

625 
Table 1.

\begin{tabular}{|c|c|c|c|c|c|c|c|c|c|c|c|c|c|c|c|c|c|c|c|c|c|c|c|}
\hline Parameter & $\mathrm{Al}$ & $\mathrm{Fe}$ & $\mathrm{Mg}$ & $\mathrm{Ti}$ & $\mathrm{Mn}$ & U & Th & $\mathrm{V}$ & $\mathrm{Sr}$ & As & $\mathrm{Cd}$ & Co & $\mathrm{Cu}$ & $\mathrm{Hg}$ & Mo & $\mathrm{Ni}$ & $\mathrm{Pb}$ & $\mathrm{Zn}$ & $\mathrm{Ag}$ & $\mathrm{Au}$ & $\mathrm{Sb}$ & $\mathrm{Bi}$ & PI \\
\hline Min. & 0.77 & 2.28 & 1.17 & 0.02 & 466 & 0.20 & 0.40 & 28.0 & 63.6 & 4.00 & 0.06 & 21.6 & 17.2 & 0.00 & 0.08 & 186 & 9.85 & 23.8 & 0.00 & 0.00 & 0.18 & 0.04 & 2.51 \\
\hline Max. & 3.46 & 12.2 & 9.72 & 0.18 & 2030 & 10.0 & 4.70 & 122 & 397 & 10000 & 27.5 & 60.0 & 1094 & 0.33 & 80.2 & 750 & 9998 & 7939 & 86.5 & 0.25 & 560 & 63.4 & 407 \\
\hline Mean & 2.45 & 4.44 & 3.26 & 0.08 & 959 & 1.06 & 2.06 & 68.9 & 180 & 770 & 3.47 & 42.1 & 122 & 0.02 & 7.01 & 467 & 3056 & 632 & 7.88 & 0.01 & 36.8 & 6.14 & 50.7 \\
\hline Median & 2.59 & 4.28 & 2.96 & 0.07 & 977 & 0.50 & 2.00 & 69.5 & 164 & 162 & 1.19 & 42.9 & 55.0 & 0.00 & 3.15 & 470 & 807 & 149 & 1.58 & 0.00 & 6.44 & 1.09 & 12.4 \\
\hline Standard & 8.80 & 4.70 & & 0.50 & 850 & & & & & 5.0 & 0.06 & 20.0 & 30.00 & 0.03 & 6.20 & 40.0 & 20.0 & 50.0 & 90.0 & 90.0 & 1.50 & & \\
\hline NSAS & None & 11.00 & & None & 30.0 & & & & & 39.0 & 39.0 & 40.0 & 37.0 & 4.00 & 10.00 & 40.0 & 36.0 & 32.0 & & & 28.0 & & \\
\hline
\end{tabular}

627 
Table 2.

\begin{tabular}{|c|c|c|c|c|}
\hline Element & Statistic & $\mathrm{CF}$ & $\mathrm{EF}$ & $\mathrm{I}_{\mathrm{geo}}$ \\
\hline \multirow{3}{*}{$\mathrm{Mn}$} & Minimum & 0.55 & 2.16 & -1.45 \\
\hline & Maximum & 2.40 & 13.5 & 0.67 \\
\hline & Mean & 1.13 & 4.39 & -0.47 \\
\hline \multirow{3}{*}{ As } & Minimum & 0.31 & 1.00 & -2.29 \\
\hline & Maximum & 769 & 4339 & 9.00 \\
\hline & Mean & 59.2 & 262 & 2.96 \\
\hline \multirow{3}{*}{$\mathrm{Cd}$} & Minimum & 0.20 & 0.65 & -2.91 \\
\hline & Maximum & 91.8 & 518 & 5.93 \\
\hline & Mean & 11.6 & 48.8 & 1.53 \\
\hline \multirow{3}{*}{ Co } & Minimum & 1.08 & 4.31 & -0.47 \\
\hline & Maximum & 3.00 & 23.5 & 1.00 \\
\hline & Mean & 2.10 & 8.08 & 0.45 \\
\hline \multirow{3}{*}{$\mathrm{Cu}$} & Minimum & 0.38 & 1.25 & -1.97 \\
\hline & Maximum & 24.3 & 137 & 4.02 \\
\hline & Mean & 2.71 & 11.4 & 0.14 \\
\hline \multirow{3}{*}{ Mo } & Minimum & 0.01 & 0.05 & -6.86 \\
\hline & Maximum & 12.9 & 73.0 & 3.11 \\
\hline & Mean & 1.13 & 4.92 & -1.95 \\
\hline \multirow{3}{*}{$\mathrm{Ni}$} & Minimum & 2.73 & 13.2 & 0.87 \\
\hline & Maximum & 11.0 & 69.8 & 2.88 \\
\hline & Mean & 6.86 & 26.4 & 2.14 \\
\hline \multirow{3}{*}{$\mathrm{Pb}$} & Minimum & 0.49 & 2.15 & -1.61 \\
\hline & Maximum & 500 & 2819 & 8.38 \\
\hline & Mean & 153 & 604 & 4.72 \\
\hline \multirow{3}{*}{$\mathrm{Zn}$} & Minimum & 0.26 & 0.86 & -2.50 \\
\hline & Maximum & 88.2 & 498 & 5.88 \\
\hline & Mean & 7.02 & 30.9 & 0.61 \\
\hline \multirow{3}{*}{$\mathrm{Sb}$} & Minimum & 0.12 & 0.42 & -3.64 \\
\hline & Maximum & 373 & 2105 & 7.96 \\
\hline & Mean & 24.5 & 111 & 1.48 \\
\hline
\end{tabular}

629

630

631

632 
Table 3.

\begin{tabular}{|c|c|c|c|c|c|c|c|c|c|c|c|c|}
\hline \multirow{2}{*}{ Parameters } & \multicolumn{6}{|c|}{ Winter Season } & \multicolumn{6}{|c|}{ Fall Season } \\
\hline & Min. & Max. & Mean & Median & STD. & $\mathrm{CV}$ & Min. & Max. & Mean & Median & STD. & $\mathrm{CV}$ \\
\hline $\mathrm{Al}$ & 2.00 & 332 & 43.6 & 10.0 & 102 & 233 & 8.00 & 7101 & 1030 & 43.0 & 2243 & 218 \\
\hline $\mathrm{Fe}$ & 10.0 & 324 & 84.3 & 24.5 & 123 & 146 & 10.0 & 1075 & 258 & 30.0 & 418 & 162 \\
\hline $\mathrm{Mn}$ & 1.00 & 55.1 & 11.6 & 2.00 & 19.5 & 168 & 1.30 & 291 & 44.7 & 5.70 & 90.8 & 203 \\
\hline $\mathrm{Cr}$ & 2.90 & 9.50 & 4.80 & 4.20 & 2.10 & 43.5 & 2.00 & 15.5 & 5.00 & 3.60 & 4.20 & 82.4 \\
\hline Co & 0.00 & 1.00 & 0.20 & 0.10 & 0.30 & 181 & 0.00 & 3.30 & 0.70 & 0.10 & 1.10 & 163 \\
\hline $\mathrm{Ba}$ & 7.70 & 65.6 & 33.4 & 37.2 & 20.2 & 60.5 & 15.2 & 112 & 45.2 & 41.2 & 27.2 & 60.3 \\
\hline $\mathrm{Ni}$ & 2.40 & 9.30 & 4.90 & 4.30 & 2.30 & 47.2 & 0.20 & 47.0 & 10.7 & 3.60 & 15.1 & 142 \\
\hline $\mathrm{Cu}$ & 1.40 & 5.30 & 3.30 & 3.20 & 1.50 & 45.5 & 1.40 & 40.4 & 8.60 & 4.30 & 11.7 & 136 \\
\hline $\mathrm{Pb}$ & 1.70 & 135 & 17.7 & 3.10 & 41.3 & 234 & 2.80 & 65.4 & 15.7 & 7.10 & 19.2 & 122 \\
\hline $\mathrm{Zn}$ & 6.50 & 182 & 53.4 & 33.1 & 60.5 & 113 & 3.90 & 342 & 85.5 & 9.50 & 124 & 145 \\
\hline Mo & 0.10 & 13.5 & 2.00 & 0.50 & 4.10 & 211 & 0.30 & 14.4 & 2.30 & 0.60 & 4.30 & 187 \\
\hline $\mathrm{Sb}$ & 0.20 & 29.2 & 5.80 & 0.70 & 10.5 & 181 & 0.30 & 64.3 & 10.5 & 1.70 & 20.4 & 194 \\
\hline As & 0.80 & 287 & 56.2 & 2.90 & 107 & 191 & 1.20 & 373 & 66.4 & 9.00 & 122 & 184 \\
\hline $\mathrm{V}$ & 0.80 & 5.40 & 2.20 & 1.80 & 1.50 & 65.2 & 0.80 & 6.50 & 2.80 & 2.80 & 1.80 & 64.0 \\
\hline
\end{tabular}


$635 \quad$ Table 4.

\begin{tabular}{|c|c|c|c|c|c|c|c|c|c|c|c|c|c|c|c|c|c|c|c|c|c|c|c|}
\hline \multirow{2}{*}{$\begin{array}{l}\text { Fruit plant type } \\
\text { PTEs }\end{array}$} & \multicolumn{4}{|c|}{ Walnut } & \multicolumn{4}{|c|}{ Cherry } & \multicolumn{4}{|c|}{ Pear } & \multicolumn{4}{|c|}{ Plum } & \multicolumn{4}{|c|}{ Grape } & \multirow[b]{2}{*}{ Acceptable limit } & \multirow[b]{2}{*}{ Toxic level } & \multirow[b]{2}{*}{$\mathrm{BCF}$} \\
\hline & Min & Max & Mean & Median & Min & Max & Mean & Median & Min & $\operatorname{Max}$ & Mean & Median & Min & Max & Mean & Median & Min & Max & Mean & Median & & & \\
\hline $\mathrm{Fe}$ & 150 & 3380 & 752 & 240 & 150 & 2780 & 480 & 530 & 160 & 11270 & 1432 & 245 & 180 & 890 & 378 & 290 & 250 & 380 & 325 & 335 & & 200 & $3.80-4.50$ \\
\hline $\mathrm{Mn}$ & 48.0 & 205 & 124 & 113 & 19.0 & 90.0 & 37.1 & 38.0 & 27.0 & 205 & 69.1 & 48.0 & 26.0 & 54.0 & 39.0 & 36.0 & 16.0 & 95.0 & 41.3 & 27.0 & & 300 & $2.40-3.20$ \\
\hline $\mathrm{Ni}$ & 0.70 & 7.10 & 2.80 & 2.25 & 1.20 & 4.60 & 2.61 & 2.10 & 1.50 & 15.7 & 6.09 & 5.50 & 1.60 & 6.50 & 2.93 & 2.60 & 1.00 & 4.80 & 2.35 & 1.80 & $0.10-3.70$ & 10.0 & $2.20-2.70$ \\
\hline Co & 0.10 & 0.30 & 0.20 & 0.13 & 0.07 & 0.26 & 0.14 & 0.20 & 0.07 & 1.71 & 0.57 & 0.43 & 0.08 & 0.31 & 0.17 & 0.15 & 0.07 & 0.28 & 0.15 & 0.13 & & & \\
\hline Mo & 0.20 & 2.30 & 1.00 & 0.64 & 0.02 & 2.46 & 0.37 & 0.23 & 0.12 & 6.16 & 0.97 & 0.24 & 0.14 & 1.17 & 0.50 & 0.41 & 0.09 & 1.31 & 0.54 & 0.39 & $0.07-1.75$ & & $0.07-1.75$ \\
\hline $\mathrm{Cu}$ & 3.30 & 31.6 & 8.90 & 4.65 & 6.14 & 33.6 & 10.1 & 11.0 & 6.00 & 106 & 19.4 & 9.97 & 3.07 & 10.2 & 7.42 & 7.65 & 4.77 & 8.98 & 6.70 & 6.53 & $5.00-30.0$ & 20.0 & $2.80-3.30$ \\
\hline $\mathrm{Pb}$ & 1.70 & 1185 & 221 & 28.9 & 2.68 & 1150 & 135 & 65.1 & 1.61 & 4443 & 490 & 21.62 & 2.98 & 195 & 48.6 & 32.9 & 2.76 & 62.8 & 32.7 & 32.6 & $5.00-10.0$ & 30.0 & $3.30-4.50$ \\
\hline $\mathrm{Zn}$ & 9.40 & 257 & 66.1 & 27.0 & 8.50 & 206 & 37.1 & 32.4 & 11.7 & 846 & 119 & 37.7 & 8.60 & 62.5 & 25.3 & 23.4 & 13.2 & 35.3 & 25.1 & 25.9 & $27.0-150$ & 100 & $2.50-3.10$ \\
\hline $\mathrm{Ag}$ & 0.00 & 0.29 & 0.05 & 0.01 & 0.00 & 0.29 & 0.03 & $1 \mathrm{E}-05$ & 0.00 & 0.96 & 0.10 & 0.00 & 0.00 & 0.03 & 0.01 & 0.01 & 0.00 & 0.02 & 0.01 & 0.01 & & & \\
\hline $\mathrm{Cd}$ & 0.01 & 0.07 & 0.03 & 0.02 & 0.01 & 0.07 & 0.02 & 0.02 & 0.01 & 0.46 & 0.14 & 0.08 & 0.01 & 0.05 & 0.02 & 0.02 & 0.01 & 0.03 & 0.02 & 0.02 & $0.05-0.20$ & 5.00 & $1.50-2.50$ \\
\hline $\mathrm{Sb}$ & 0.05 & 21.7 & 4.09 & 0.48 & 0.07 & 22.1 & 2.41 & 1.25 & 0.04 & 60.6 & 6.71 & 0.29 & 0.05 & 2.76 & 0.67 & 0.47 & 0.05 & 0.87 & 0.46 & 0.45 & & & $2.60-3.80$ \\
\hline $\mathrm{Cr}$ & 0.90 & 2.90 & 1.42 & 1.15 & 1.00 & 2.30 & 1.41 & 1.80 & 1.00 & 7.10 & 1.94 & 1.30 & 1.00 & 1.70 & 1.32 & 1.30 & 1.10 & 2.20 & 1.50 & 1.35 & & & \\
\hline $\mathrm{Ti}$ & 9.00 & 19.0 & 12.3 & 11.5 & 9.00 & 17.0 & 11.1 & 12.0 & 10.0 & 37.0 & 15.5 & 13.0 & 11.0 & 41.0 & 16.7 & 14.0 & 11.0 & 19.0 & 13.8 & 12.5 & & & \\
\hline $\mathrm{Se}$ & 0.20 & 0.50 & 0.32 & 0.30 & 0.10 & 0.50 & 0.28 & 0.30 & 0.10 & 0.50 & 0.32 & 0.30 & 0.20 & 0.40 & 0.31 & 0.30 & 0.10 & 0.40 & 0.28 & 0.30 & & & \\
\hline $\mathrm{Au}$ & 3.30 & 91.5 & 29.4 & 16.1 & 3.70 & 31.8 & 12.7 & 15.0 & 3.40 & 115 & 30.2 & 10.2 & 4.10 & 54.6 & 18.7 & 12.6 & 4.00 & 9.70 & 6.85 & 6.85 & & & \\
\hline B & 95.0 & 277 & 179 & 176 & 29.0 & 91.0 & 54.9 & 29.0 & 23.0 & 83.0 & 37.5 & 34.5 & 30.0 & 67.0 & 42.7 & 42.0 & 28.0 & 54.0 & 39.8 & 38.5 & & & \\
\hline $\mathrm{Hg}$ & 13.0 & 28.0 & 20.2 & 20.5 & 9.0 & 32.0 & 19.8 & 32.0 & 9.00 & 41.0 & 21.2 & 21.0 & 12.0 & 19.0 & 15.9 & 15.0 & 6.00 & 20.0 & 13.0 & 13.0 & $0.002-0.086$ & & \\
\hline
\end{tabular}


Winter Season

\begin{tabular}{|c|c|c|c|c|c|c|c|c|c|c|c|}
\hline \multicolumn{6}{|c|}{ Estimated Daily Intake (EDI) } & \multicolumn{5}{|c|}{ Hazard Quotient (HQ) } & \multirow{2}{*}{$\begin{array}{c}\text { Carcinogenic Risk (CR) } \\
\text { As }\end{array}$} \\
\hline Sample & As & $\mathrm{Ni}$ & $\mathrm{Pb}$ & $\mathrm{Zn}$ & $\mathrm{Sb}$ & As & $\mathrm{Ni}$ & $\mathrm{Pb}$ & $\mathrm{Zn}$ & $\mathrm{Sb}$ & \\
\hline GS1a & 0.00003 & 0.00020 & 0.0001 & 0.0059 & 0.00001 & 0.08637 & 0.00130 & 0.02128 & 0.01965 & 0.01296 & 0.00002 \\
\hline GS1b & 0.00006 & 0.00011 & 0.0002 & 0.0025 & 0.00002 & 0.21592 & 0.00324 & 0.06570 & 0.00837 & 0.03887 & 0.00004 \\
\hline GS2 & 0.00011 & 0.00008 & 0.0005 & 0.0003 & 0.00001 & 0.37787 & 0.00567 & 0.15639 & 0.00111 & 0.01457 & 0.00007 \\
\hline GS3 & 0.00929 & 0.00009 & 0.0001 & 0.0010 & 0.00095 & 30.97436 & 0.46462 & 0.02313 & 0.00342 & 2.36761 & 0.00540 \\
\hline GS4 & 0.00736 & 0.00030 & 0.0044 & 0.0044 & 0.00069 & 24.52901 & 0.36794 & 1.24558 & 0.01460 & 1.71903 & 0.00428 \\
\hline GS5 & 0.00003 & 0.00027 & 0.0001 & 0.0011 & 0.00001 & 0.09717 & 0.00146 & 0.03054 & 0.00371 & 0.02753 & 0.00002 \\
\hline GS6 & 0.00004 & 0.00018 & 0.0001 & 0.0013 & 0.00001 & 0.12955 & 0.00194 & 0.02684 & 0.00425 & 0.01700 & 0.00002 \\
\hline GS7 & 0.00105 & 0.00013 & 0.0001 & 0.0003 & 0.00014 & 3.50877 & 0.05263 & 0.01573 & 0.00108 & 0.34494 & 0.00061 \\
\hline GS8 & 0.00015 & 0.00015 & 0.0001 & 0.0002 & 0.00003 & 0.49663 & 0.00745 & 0.02961 & 0.00079 & 0.07126 & 0.00009 \\
\hline GS9 & 0.00007 & 0.00010 & 0.0001 & 0.0002 & 0.00003 & 0.24831 & 0.00372 & 0.01943 & 0.00070 & 0.06802 & 0.00004 \\
\hline Safe limits & $5 \times 10^{-8}$ & $2 \times 10^{-2}$ & $2.5 \times 10^{-2}$ & $7 \times 10^{-3}$ & $6 \times 10^{-3}$ & 1 & 1 & 1 & 1 & 1 & $1 \times 10^{-4}$ \\
\hline
\end{tabular}

$\mathbf{3 3} \mid \mathrm{P}$ a g e 
Table 6.

Fall Season

\begin{tabular}{|c|c|c|c|c|c|c|c|c|c|c|c|}
\hline \multicolumn{6}{|c|}{ Estimated Daily Intake (EDI) } & \multicolumn{5}{|c|}{ Hazard Quotient (HQ) } & \multirow{2}{*}{$\begin{array}{c}\text { Carcinogenic Risk (CR) } \\
\text { As }\end{array}$} \\
\hline Sample & As & $\mathrm{Ni}$ & $\mathrm{Pb}$ & $\mathrm{Zn}$ & $\mathrm{Sb}$ & As & $\mathrm{Ni}$ & $\mathrm{Pb}$ & $\mathrm{Zn}$ & $\mathrm{Sb}$ & \\
\hline GS1a & 0.00036 & 0.00013 & 0.0008 & 0.0035 & 0.00006 & 1.20918 & 0.00063 & 0.24153 & 0.01171 & 0.13927 & 0.00021 \\
\hline GS1b & 0.00088 & 0.00085 & 0.0021 & 0.0111 & 0.00011 & 2.94737 & 0.00423 & 0.60521 & 0.03696 & 0.26397 & 0.00051 \\
\hline GS2 & 0.00022 & 0.00002 & 0.0001 & 0.0001 & 0.00003 & 0.72335 & 0.00010 & 0.03609 & 0.00042 & 0.07773 & 0.00013 \\
\hline GS3 & 0.01206 & 0.00002 & 0.0006 & 0.0003 & 0.00208 & 40.21592 & 0.00010 & 0.15824 & 0.00108 & 5.20729 & 0.00701 \\
\hline GS4 & 0.00617 & 0.00001 & 0.0006 & 0.0030 & 0.00085 & 20.56680 & 0.00003 & 0.17490 & 0.01001 & 2.12308 & 0.00359 \\
\hline GS5 & 0.00004 & 0.00023 & 0.0001 & 0.0002 & 0.00001 & 0.12955 & 0.00113 & 0.02591 & 0.00079 & 0.02753 & 0.00002 \\
\hline GS6 & 0.00015 & 0.00010 & 0.0002 & 0.0087 & 0.00005 & 0.50742 & 0.00049 & 0.06015 & 0.02910 & 0.13036 & 0.00009 \\
\hline GS7 & 0.00135 & 0.00011 & 0.0001 & 0.0002 & 0.00017 & 4.50202 & 0.00053 & 0.02961 & 0.00055 & 0.43320 & 0.00078 \\
\hline GS8 & 0.00011 & 0.00152 & 0.0002 & 0.0002 & 0.00002 & 0.35628 & 0.00761 & 0.07033 & 0.00070 & 0.04130 & 0.00006 \\
\hline GS9 & 0.00014 & 0.00048 & 0.0002 & 0.0003 & 0.00003 & 0.47503 & 0.00240 & 0.05367 & 0.00097 & 0.07611 & 0.00008 \\
\hline Safe limits & $5 \times 10^{-8}$ & $2 \times 10^{-2}$ & $2.5 \times 10^{-2}$ & $7 \times 10^{-3}$ & $6 \times 10^{-3}$ & 1 & 1 & 1 & 1 & 1 & $1 \times 10^{-4}$ \\
\hline
\end{tabular}

34 |P a g e 


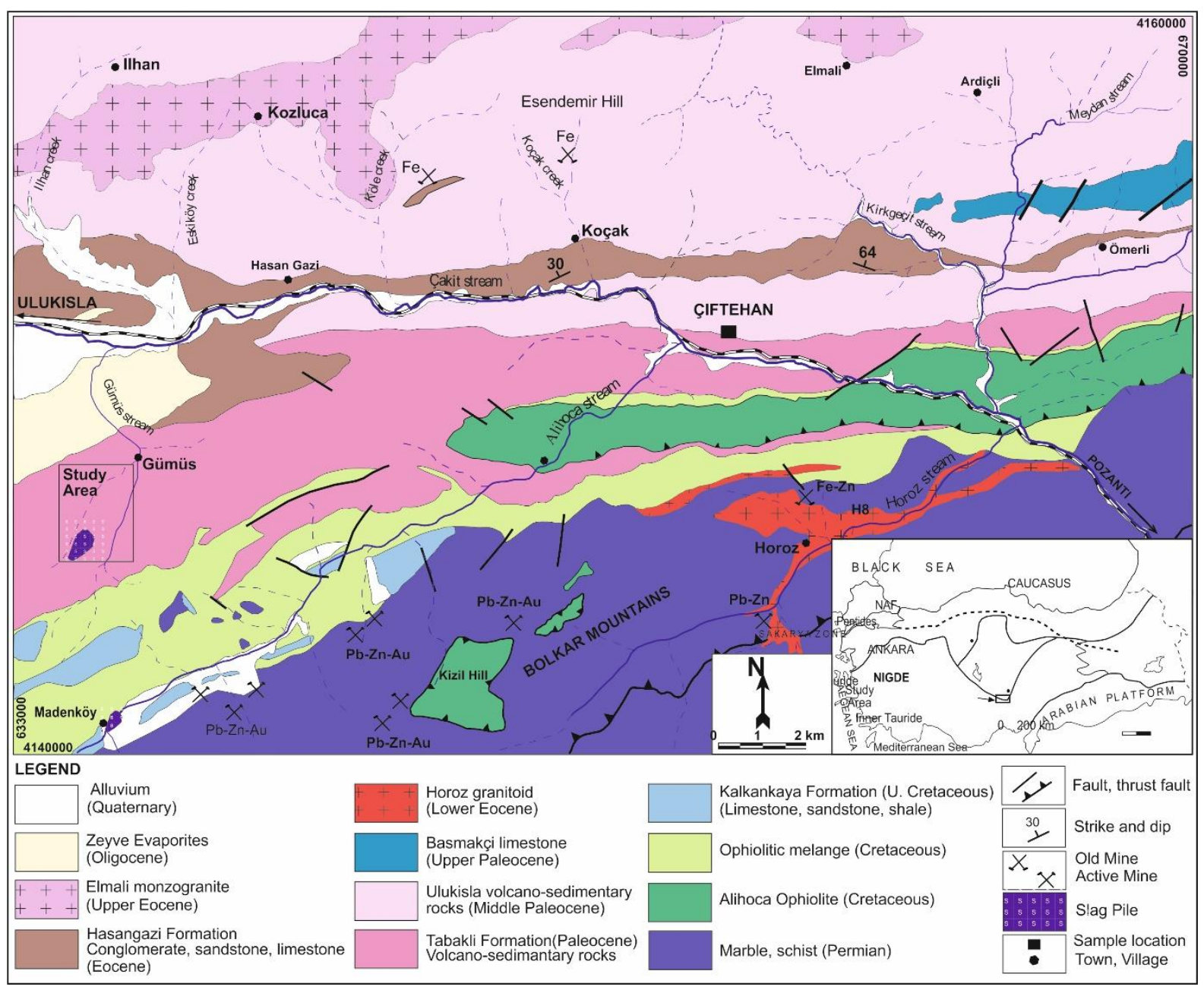

$640 \quad$ Figure 1. 


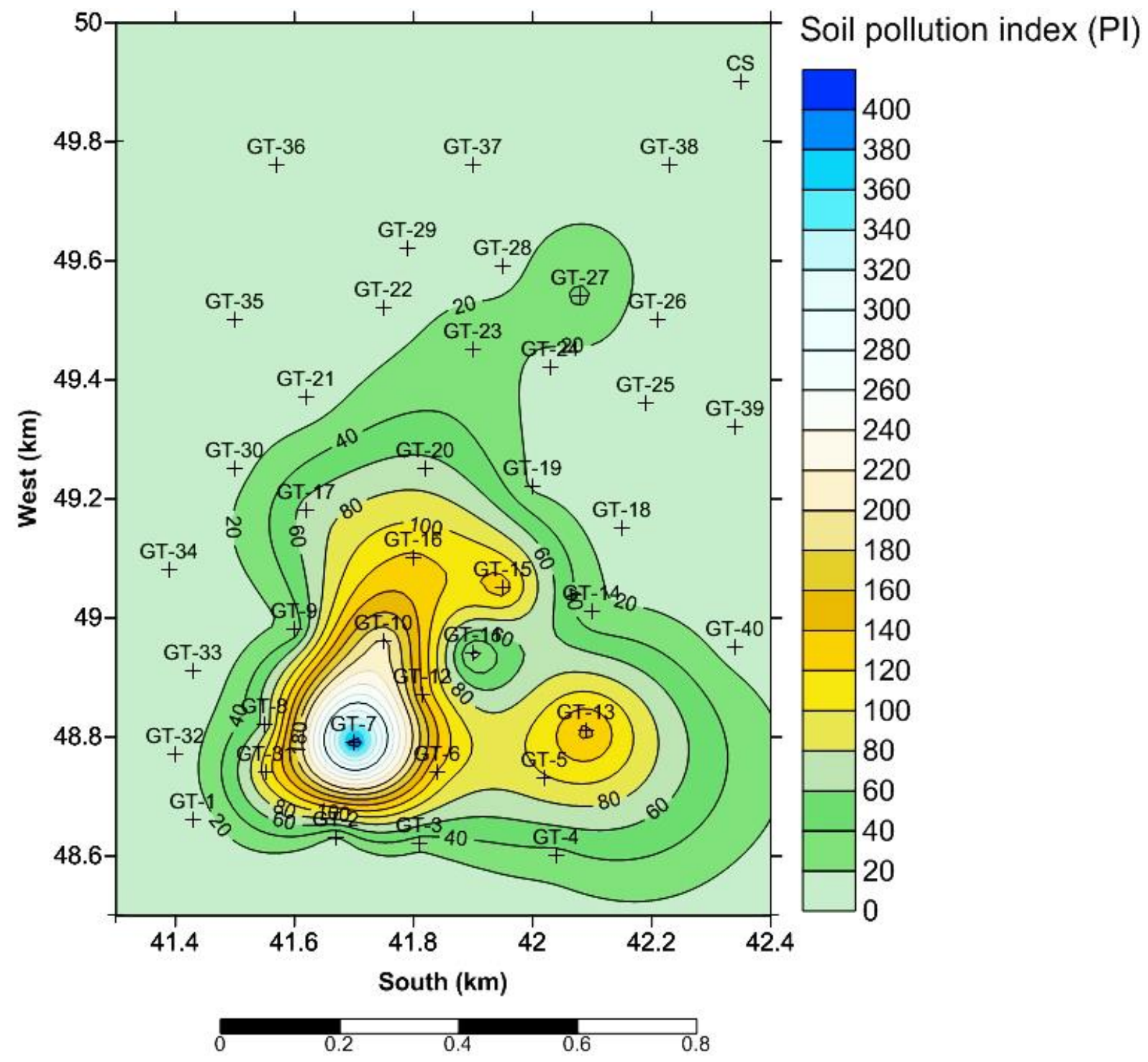

642 Figure 2. 

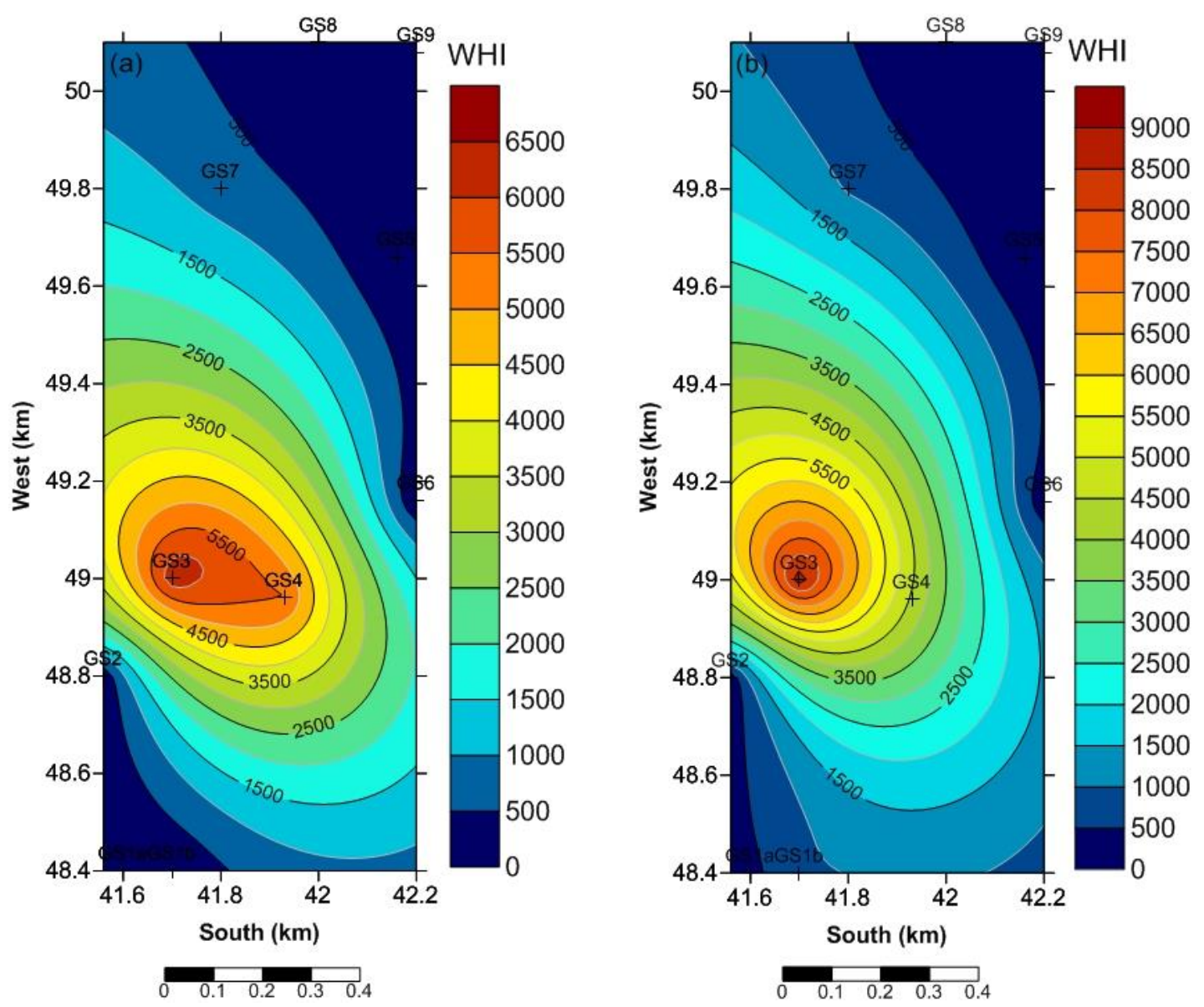

\section{$644 \quad$ Figure 3.}




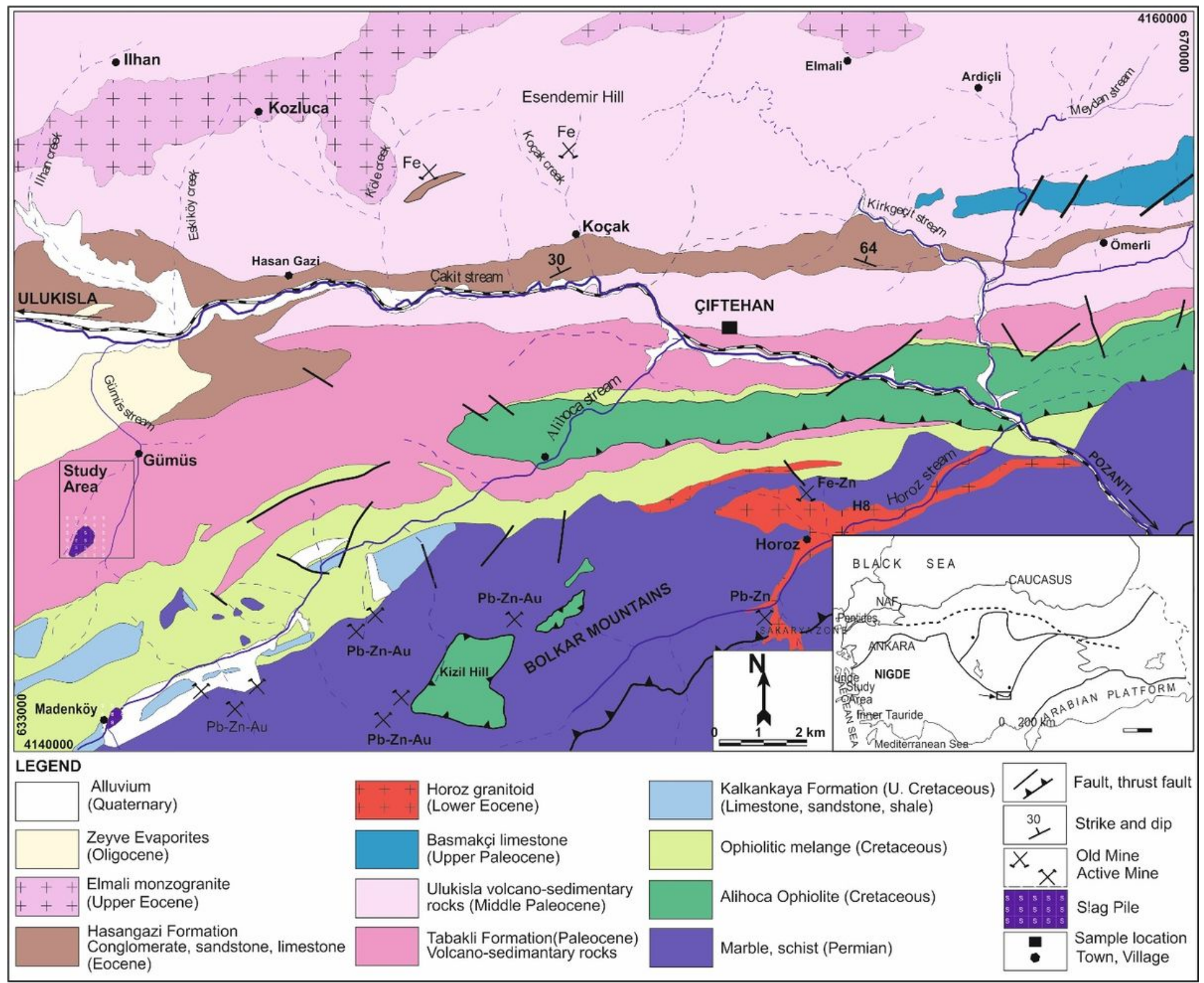

\section{Figure 1}

Location and geology map of the study area (after Lermi and Sunkari 2020) Note: The designations employed and the presentation of the material on this map do not imply the expression of any opinion whatsoever on the part of Research Square concerning the legal status of any country, territory, city or area or of its authorities, or concerning the delimitation of its frontiers or boundaries. This map has been provided by the authors. 


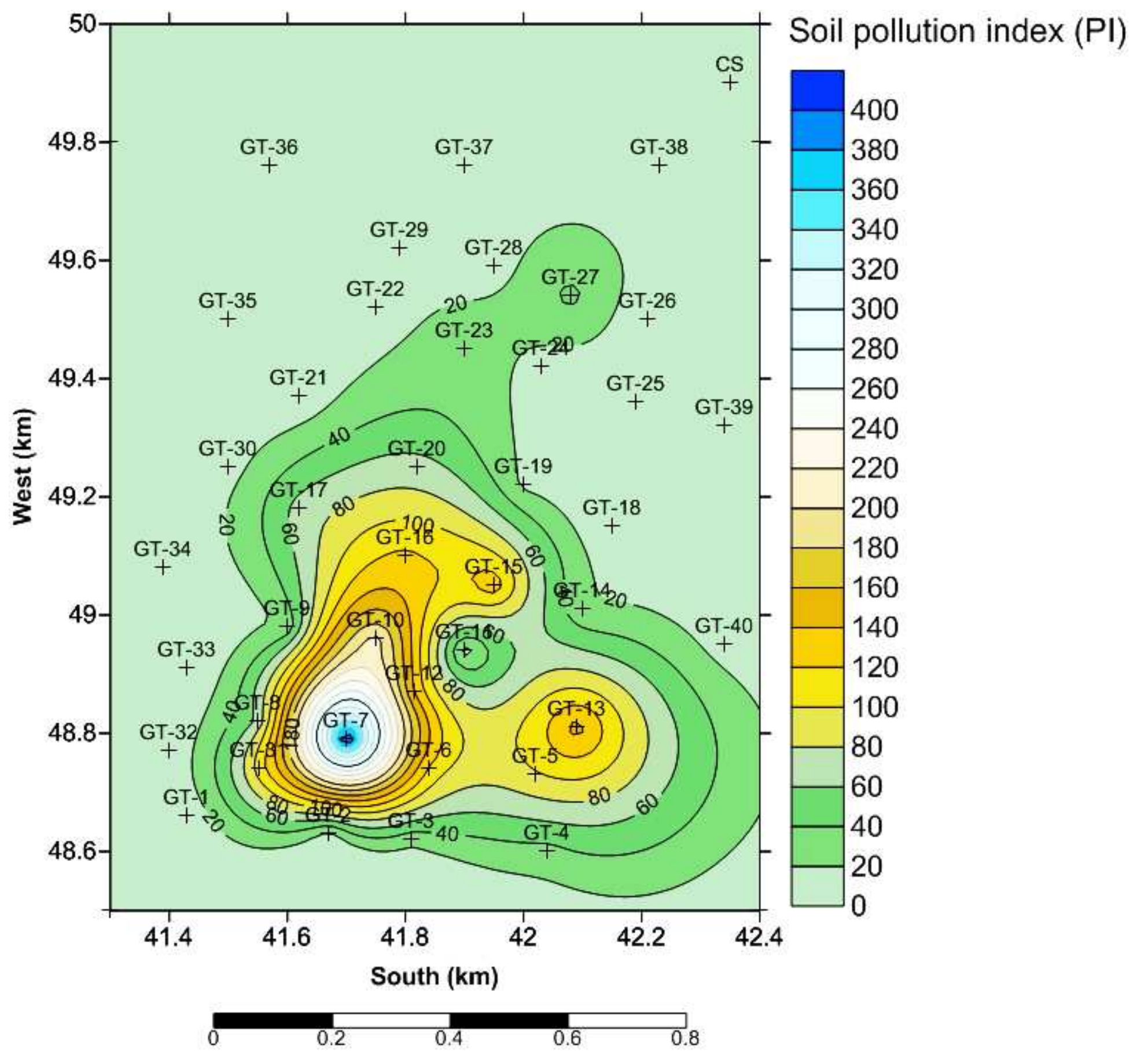

Figure 2

Spatial distribution of soil pollution index values Note: The designations employed and the presentation of the material on this map do not imply the expression of any opinion whatsoever on the part of Research Square concerning the legal status of any country, territory, city or area or of its authorities, or concerning the delimitation of its frontiers or boundaries. This map has been provided by the authors. 


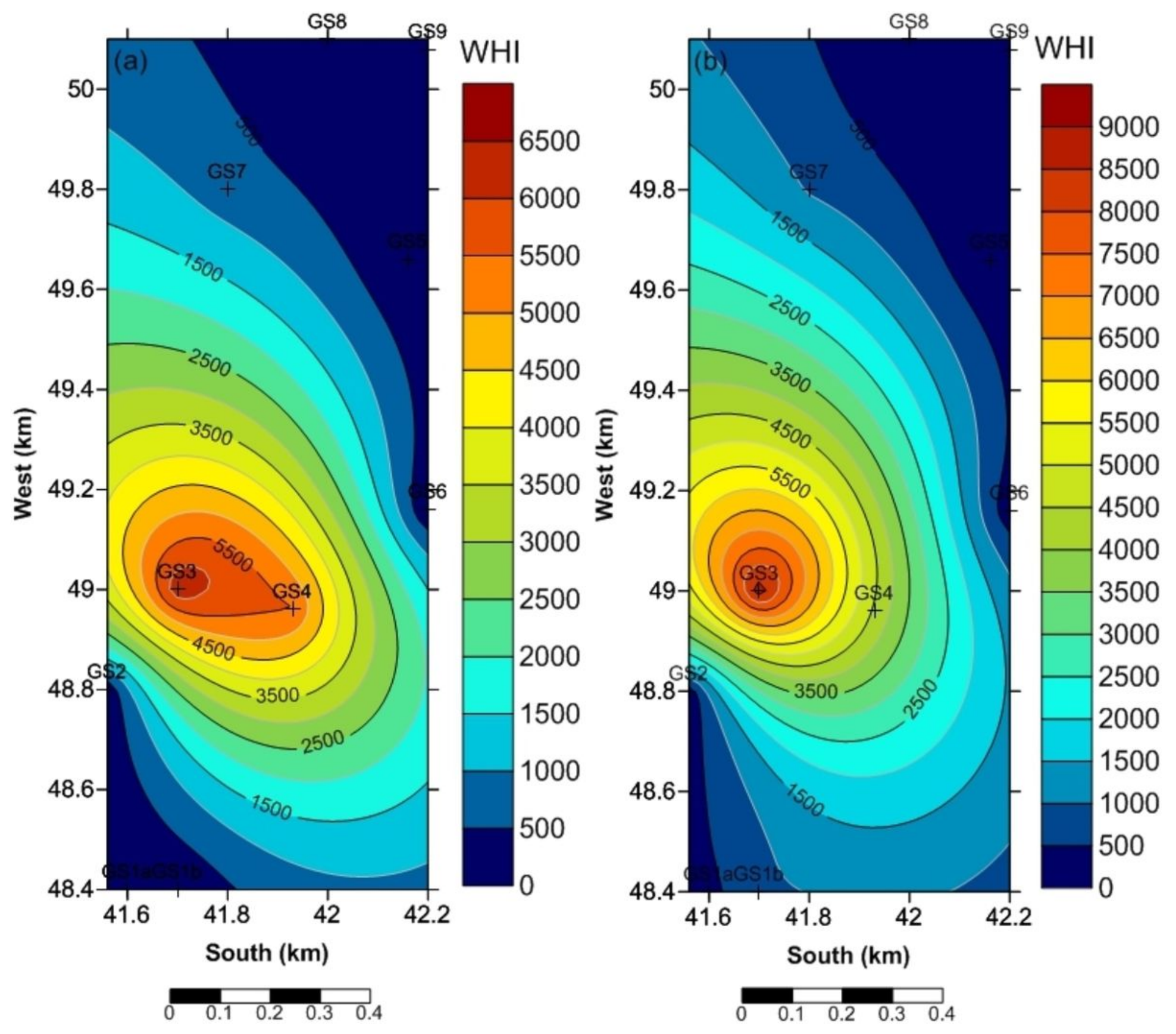

Figure 3

Water hazard index (WHI) for (a) winter season and (b) fall season 